\title{
Short- and Long-Term Effects of Financial Flows on Economic Growth
}

\author{
Amna Zardoub ${ }^{1+}$, Riadh El Abed ${ }^{2}$ \\ ${ }^{1}$ University of Sousse, Tunisia \\ ${ }^{2}$ University of Tunis El Manar, Tunisia
}

\begin{abstract}
Globalization represents a central research activity and remains an increasingly controversial phenomenon in economics. It corresponds to a subject that can be criticized through its impact on national economies. In contrast, the world economy is evolving in a liberalized environment wherein Foreign Direct Investment plays a fundamental role in the economic development of each country. The advent of financial flows -Foreign Direct Investment, remittances, and official development assistance- can be key factors in economic development. This article analyzes the effect of financial flows on economic growth in developing countries. Empirically, different approaches have been employed. As part of this work, an attempt was made to use a combined autoregressive distributed lag panel approach to study the short- and long-term effects of financial flows on economic growth. The results indicate ambiguous effects.
\end{abstract}

Keywords: Economic growth, Foreign direct investment, Remittances, Official development assistances, Panel ARDL

JEL Classifications: F22, Q56

Received 29 July 2019, Revised 5 November 2019, Accepted 6 November 2019

\section{Introduction}

Financial flows play an important role in the economies of developing countries. The relationship among Foreign Direct Investment (FDI), remittances, Official Development Assistance (ODA), and economic growth has not yet received unanimous agreement from researchers and policymakers. This is a widely debated and popular subject in international economics.

In recent decades, various developing countries, specifically the African countries have higher rates of economic growth. Nevertheless, the major challenge for these countries is in their ability to sustain this growth over the long run. African governments are characterized by lower tax revenues and a very low level of savings compared to other regions. They adopt external

+Corresponding Author: Amna Zardoub

FSEG Sousse, Doctorante en Sciences Economiques, Laboratoire d'économie appliquée et simulation. University of Sousse, 65 rue Avicène Moknine 5050, Monastir/Tunisie, Tunisia, Tel: 51879905, Email: zardoubamna@gmail.com Co-Author: Riadh El Abed

ISIG Kairouan, Maitre Assistant en sciences économiques, Laboratoire d'Ingénierie Financière et Economique (LIFE), FSEG Tunis, Tunisia. Email: riadh.abed@gmail.com

Acknowledgements: The authors are grateful to an anonymous referee and the editor for their helpful comments and suggestions. Any errors or omissions are, however, our own. 
sources of financing such as the official development assistance, the FDI and remittances.

Almfraji et al. (2014) show that these external sources of finance have been proved to play an important role in development and economic growth. Figure 1 shows the evolution of FDI, remittances and ODA to low- and middle-income countries between 2004 2016. The data reveal that FDI is significantly larger than the other two sources of foreign capital. As can be seen, in developing countries remittances are much larger than foreign aid. ODA appears to be fairly stable in relation to FDI inflows and remittances. This reflects the importance of ODA as a stable source of development for developing countries in recent years.

Figure 1. Evolution of FDI, remittances and ODA to low- and middle-income countries between 2004 2016

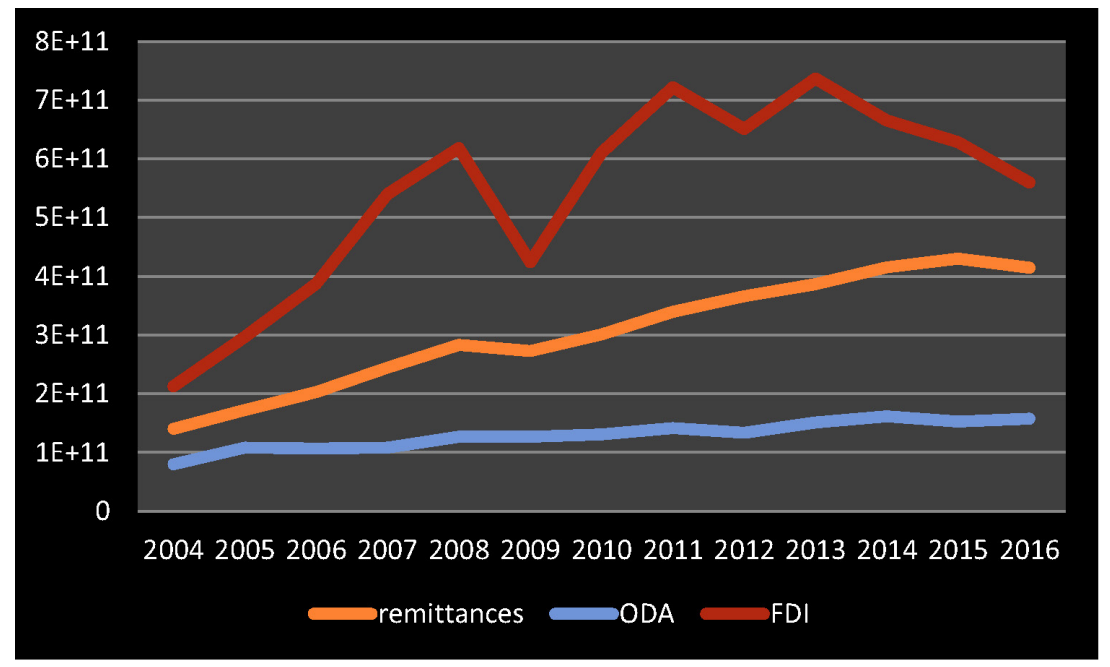

(Source) UNCTAD (2018), (www.unctad.org/fstatistics) and The World Bank (2018)

Figure 2 shows migrant transfers by region as a percentage of Gross Domestic product (GDP) between 2014 2016. The chart shows that migrant remittances are significantly larger than ODA in South Asia in 2014. Interestingly, since 2014, remittances to the Middle East and North Africa have also increased sharply. Similarly remittances from migrants to sub-Saharan Africa also increased from 2014 to 2015 . 
Figure 2. Migrant transfers by region as a percentage of GDP between 2014 2016

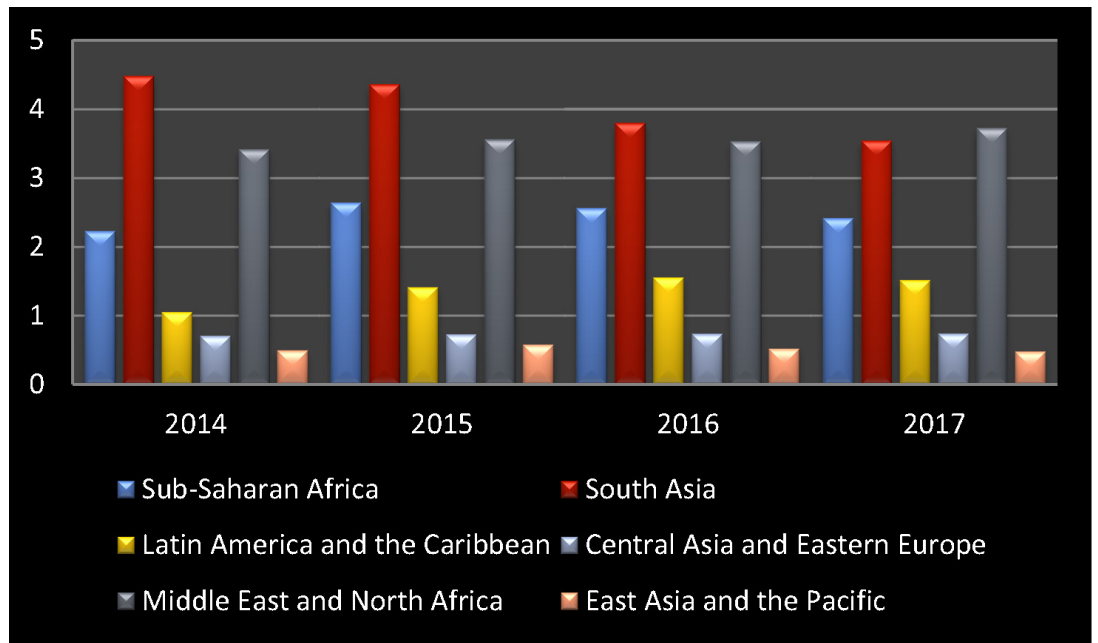

(Source) The World Bank (2018)

Figure 3 shows the share of official development assistance in each region as a percentage of GNI in 2017. The figure shows that in 2017, sub-Saharan Africa has the lion's share of ODA, ahead of the Middle East, North Africa and South Asia.

Figure 3. The share of official development assistance in each region as a percentage of GNI in 2017

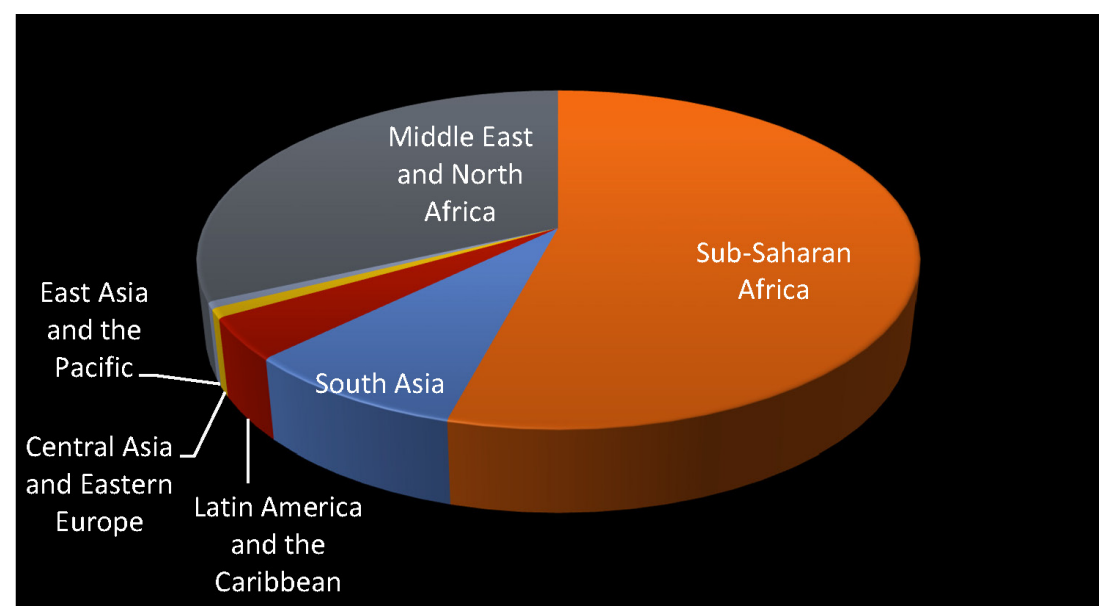

(Source) The World Bank (2018)

This work makes empirical contributions to the existing relationship between financial flows and economic growth. Indeed, the mains objectives are the following: Do remittances and foreign aid and FDI really spur more economic growth in developing countries? Is there a permanent or temporary effect of financial flows on economic growth? Various work tried to answer the 
first question (Driffield and Jones 2013, Nwaogu and Ryan 2015). Nevertheless, this study differs from this work for two reasons. First, we contribute to the debate by modeling the possibly short-run and long-run relationship between financials flows such as FDI, ODA and remittances on economic growth in developing countries. Empirically, we focus on three types of estimators such as the Mean Group (MG), the Pooled Mean Group (PMG) and the Dynamic Fixed Effect (DFE). The PMG allow us to distinguish between short-run and long-run effect and to control for panel heterogeneity. Second, we investigate whether the interaction between the three financial flows and economic growth varies with the level of economic development. For this reason, we divide our sample in two panel data, namely: lower-middle-income and upper middle income for the period span from 1990 to 2017.

The rest of the paper is organized as follows. Section II reviews the related literature. Section III presents the data econometric methodology. Section IV displays and discusses the empirical findings and their interpretation, while section $\mathrm{V}$ provides our conclusions.

\section{Literature Review}

Theoretically, the first strand of research focuses on the impact of FDI, remittances, and ODA on economic growth. FDI can bolster economic growth in a number of ways. Moreover, the impact of FDI on exports of local businesses reveals indirect effects (Caves 1996). Foreign affiliates may impact the host country's manufacturing exports in several ways. For example, local businesses can increase exports by observing the export activities of multinational firms and by using the transport, communications, and financial services infrastructure developed to support these activities (Haddad and Harrison 1993). Another indirect effect involves the influence of FDI on the competitiveness of enterprises in host countries and the spread of new technologies. Vertical FDI is an export-oriented platform, and multinational companies create a subsidiary abroad for re-exports. Firms set up in a foreign country for re-exports seek cheap labor or cheap raw material; in other words, they seek cost efficiencies (Helpman 1984).

In the empirical context Javaid (2017) examined the effect of external capital flows (remittances, FDI, and ODA) on Pakistan's GDP growth over the period 1973 2014. The results suggest that FDI and ODA had overall significant and positive impact on Pakistan's GDP growth in both the short and long terms. Remittances play no significant role in explaining the variations in Pakistan's economic growth. According to the author, the relationship between remittances and economic growth can be explained by the fact that the former are used for consumption to increase well-being rather than to improve overall economic growth. In addition, a large flow of remittances can negatively impact growth, given that participation in the labor market is negligible. Another reason for the negative impact of migrants' remittances on economic growth 
is the unproductive use of these flows.

Households use their money to purchase imported products. The inflow of migrants' remittances causes the real exchange rate to appreciate, which reduces the exports in the economy. Olubiyi (2014) studied the relationship between remittances and imports and that between remittances and exports using Nigeria as an example for the period 1980 2012. Results show that remittances positively impact imports and exports and, thus, countries' trade openness.

Phiri (2017) examined the impact of foreign aid on the economic growth of 12 countries in sub-Saharan Africa from 1995 to 2014. Results show that the aid has a statistically insignificant and negative impact on economic growth because aid does not promote economic growth if it is misallocated or used inefficiently. In another study, Minoiu and Reddy (2008) analyzed the effect of ODA on the economic growth of developing countries over the period 1960 2000. Their findings indicate that development aid has a positive and important effect on economic growth. Thus, economic growth can attract aid flows as a result of efficient use. Ouattara (2006) studied the effect of aid on the fiscal behavior of developing countries over the period 1980 2000. Results suggest that aid has a positive and significant impact on public investment and development spending.

Bhavan et al. (2011) examined the relationship between foreign aid and FDI in South Asian countries from 1995 to 2007. Results revealed that foreign aid attracts FDI in the region. This effect is explained generally because aid is given in the form of aid for trade, which is a complementary factor to FDI in South Asian countries. Selaya and Al (2008) studied the relationship between foreign aid and FDI. Foreign aid can improve the marginal productivity of capital by investment in public infrastructure projects and human capital. Karakaplan et al. (2005) studied the effect of aid on FDI and concluded that aid-recipient countries are more likely to obtain FDI in case of good governance.

Coon and Neumann (2015) studied the relationship between remittances and FDI in 118 developing countries from 1980 to 2010 and found that an increase of $10 \%$ in FDI inflows corresponds to a $3.6 \%$ increase in remittances. Such results suggest that migrant remittances and FDI are complementary. Remittances increase with a large influx of FDI providing development finance to countries that send a significant number of migrants abroad. Remittances increase FDI by providing relevant information and reducing uncertainty. However, migrants can orient their income toward national investments or through FDI flows by positively impacting the economy of their native countries.

Lahiri and Raimondos-Møller (2000) studied the relationship between migrant remittances and foreign aid. Remittances can affect the foreign aid to the country of origin. The authors claimed that foreign ethnic groups pressurize host countries for the benefit of their native countries. However, potential investors among migrants living in donor countries are pushing toward specific types of aid and critical bottlenecks. As a result, they can assist in promoting the productivity 
of their remittances.

The relationship between migrant remittances and foreign aid is complementary. An increase in local investment financed by remittances could stimulate the impact on infrastructure and institutions financed by foreign aid by better utilizing commercial opportunities and, thus, bolstering economic growth of the countries of origin. In addition, migrant remittances favor economic relations between source and destination countries by reducing volatility typical of aid disbursements (Lensink and Morrissey 2000, Kodama 2012).

Minasyan and Nunnenkamp (2016) argued that foreign aid does not lead to any improvement in the infrastructure, institutions and economic growth of the recipient country. This discourages migrants from sending funds to and investing in their home countries.

\section{Data and Empirical Methodology}

This empirical analysis mainly studies the short- and long-term effects of financial flows, namely, FDI, migrant remittances, and ODA, on economic growth. For this, a global sample of 33 developing countries ranked by income level is considered: lower-middle-income countries (Bangladesh, Bolivia, Cameron, Ivory Coast, Egypt, El Salvador, Ghana, Guatemala, Honduras, India, Indonesia, Kenya, Morocco, Nigeria, Pakistan, Philippines, Sudan, and Tunisia) and upper-middle-income countries (Algeria, Argentina, Botswana, Brazil, China, Colombia, Costa Rica, Malaysia, Mexico, Namibia, Panama, Peru, Thailand, Turkey, and Venezuela). The period studied was from 1990 to 2017. All data, barring that for FDI, are sourced from the World Development Indicators (WDI); FDI data are sourced from UNCTAD.

To study the short- and long-term effects of financial flows on economic growth, we consider an empirical approach based on the panel Auto Regressive Distributed Lag (ARDL) approach. This model makes it possible to distinguish between the short- and long-term effects and is based on three estimators, namely, MG, PMG, and DFE.

\section{A. Specificity of panel ARDL}

To study the long-term effect of FDI, migrant remittances, and ODA on economic growth, the following basic model is used:

$$
G D P \text { per capita } a_{i t}=\alpha_{0}+\alpha_{1} F D I_{i t}+\alpha_{2} T R_{i t}+\alpha_{3} O D A_{i t}+\varepsilon_{i t}
$$

where GDP per capita $i t$ is the per capita GDP growth rate for country $i$ on date $t, F D I_{i t}$ is the stock of FDI as a percentage of GDP, $T R_{i t}$ is the transfer of migrants as a percentage 
of GDP, $O D A_{i t}$ represents ODA as a percentage of GNP, and $\varepsilon_{i t}$ is the error term. Traditional estimation methods do not permit the study of the adjustment of variables to short- and long-term equilibrium situations. For this reason, we employed the panel ARDL model. This approach appears essential in controlling the heterogeneity in the relationship that exists between variables integrating the specific individual effects.

Referring to the work of Pesaran and Shin (1996), the ARDL (p, q) model is specified by the following equation:

$$
Y_{i t}=\sum_{j=1}^{p} \varphi_{i, j} Y_{i, t-j}+\sum_{j=0}^{q} \delta_{i, j} X_{i, t-j}+\vartheta_{i}+\varepsilon_{i t}
$$

where $i=1,2, \ldots, N$ is the number of countries; $t=1, \ldots, T$ is the time; $j$ is the number of lags; $X_{i, t}$ is the vector of variables related to financial flows; and $\vartheta_{i}$ is the specific fixed effect of the countries. To consider the adjustment coefficient and long-term dynamics, Equation (2) is reparametrized as follows:

$$
\Delta Y_{i t}=\varnothing_{i}\left(Y_{i, t-1}-\theta_{i} X_{i, t}\right)+\sum_{j=1}^{p-1} \varphi_{i, j}^{\prime} \Delta Y_{i, t-j}+\sum_{j=0}^{q-1} \delta_{i, j}^{\prime} \Delta X_{i, t-j}+\vartheta_{i}+\varepsilon_{i t}
$$

where $\varnothing_{i}$ is the adjustment coefficient of the long-term dynamics, $\theta_{i}$ indicates the long-term equilibrium relationship between $Y_{i, t}$ and $X_{i, t}$, and $\varphi_{i, j}^{\prime}$ and $\delta_{i, j}^{\prime}$ represent the short-term coefficients linking economic growth with its past values and the variables of interest, $X_{i, t}$. A long-term relationship between growth and financial flows exists if $\varnothing_{i}$ is negative and significant, leading to a cointegration relationship between $Y_{i, t}$ and $X_{i, t}$. To estimate Equation (3), three estimation methods are used: MG developed by Pesaran and Smith (1995), PMG developed by Pesaran et al. (1999), and the DFE.

\section{B. PMG estimator}

The main characteristic of PMG is that it allows short-term coefficients, including intercepts, speed of adjustment to long-term equilibrium values, and error variances, to be heterogeneous by country, whereas the long-term slope coefficients are restricted to be homogeneous across countries. This is particularly useful where there certain reasons exist for accepting that the long-term equilibrium relationship between the variables is similar across countries or, at least, a subset of countries. The short-term adjustment is allowed to be country-specific, given the widely different impact of the vulnerability of financial crises and external shocks, stabilization policy, monetary policy, and so on. However, there are several requirements to be considered when establishing the validity, consistency, and efficiency of this methodology. 


\section{MG estimator}

The MG technique introduced by Pesaran and Smith (1995) calls for estimating separate regressions for each country and calculating the coefficients as invariant means of the estimated coefficients for the individual countries. This approach does not impose any restrictions but allows for all coefficients to vary and be heterogeneous in the long and short terms. However, the condition essential to establish the consistency and validity of this approach is to have a sufficiently large time-series dimension of the data.

\section{DFE estimator}

The DFE estimator is very similar to PMG and restricts the slope coefficient and error variances to be equal across countries in the long term. The DFE model further restricts the speed of adjustment coefficient and the short-term coefficient to be equal. However, the model features country-specific intercepts. Moreover, the DFE has a cluster option to estimate the intragroup correlation with the standard error (Blackburne and Frank 2007).

\section{Empirical Findings}

\section{A. Stationarity tests}

Before proceeding with the estimation of the ARDL model as a panel, it is necessary to study the stationarity of the variables for the lower-middle-income countries and the upper-middle-income countries. Noting that the order of integration of the variables is not essential for applying ARDL model as long as the variable of interest are I(0) and (1), (Pesaran and Smith (1995), Pesaran (1997), Pesaran et al. (1999)), we introduce these tests just to make sure that no series exceeds the integration of order I(1).

Tables 1 and 2 reported the results of stationarity tests using various types of tests namely the ADF, PP, IPS and Hadri-LM tests. In what follows, we will conduct an empirical literature regarding these different tests of unit root used. Results indicate the evidence of stationarity to two series in level such as $T R$ and $O D A$ for the lower-middle-income countries. The GDP per capita and $F D I$ are stationary in first difference. However, for the upper-middle-income countries, all series are stationary in the first difference. Due to the existence of mixed levels of integration among series we proceed to apply the panel ARDL approach rather than traditional static or panel cointegration test (Asteriou and Monastiriotis 2004).

We can use the panel ARDL model for the two groups of countries. In what follows, the employee stationarity tests are theoretically introduced. 


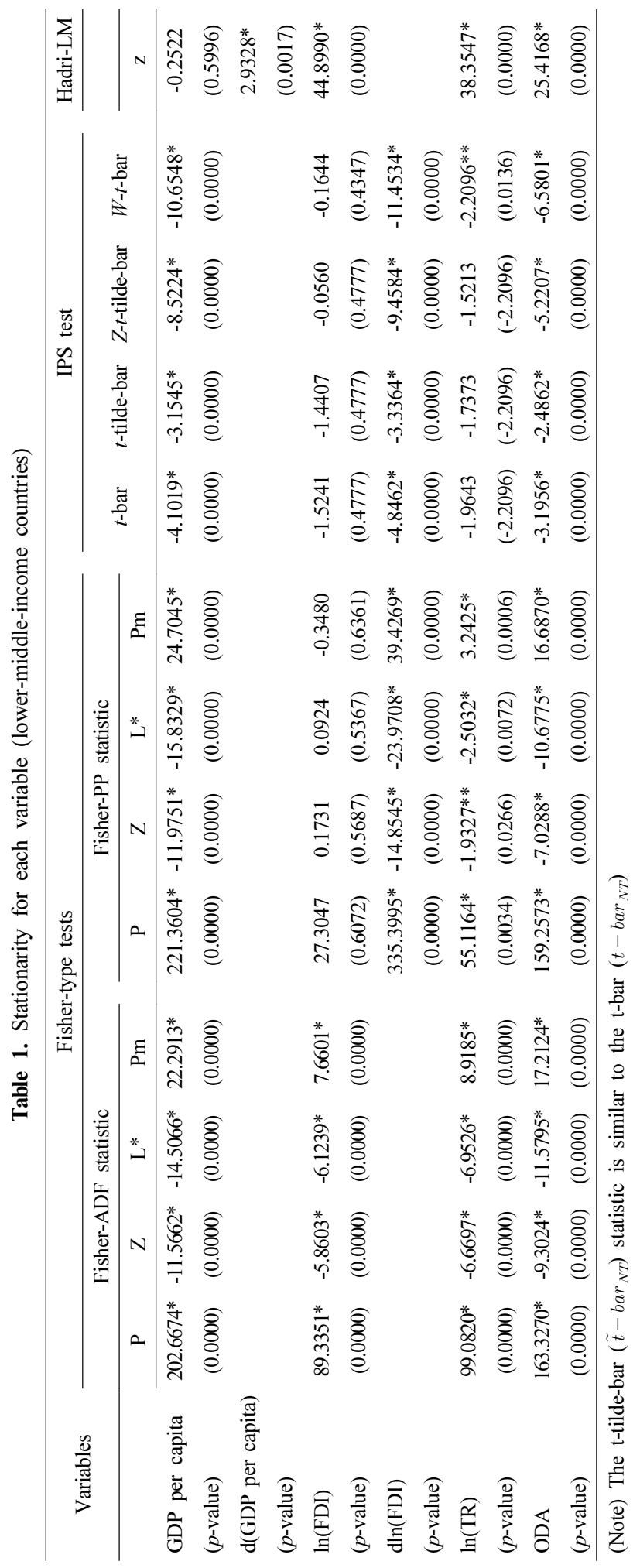


714 Journal of Economic Integration Vol. 34, No. 4

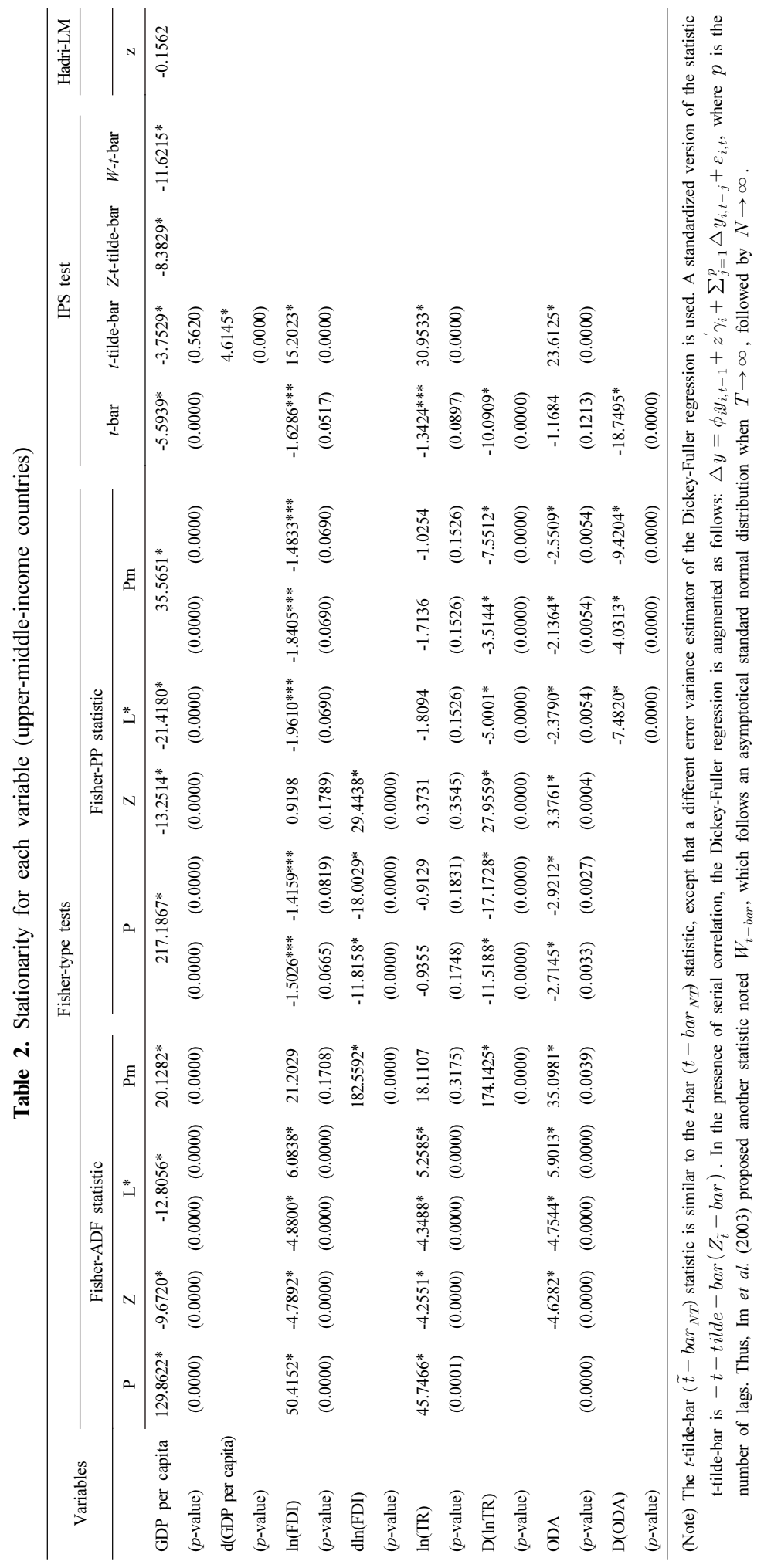




\section{Im, pesaran, and shin (2003) test}

Im et al. (1997) proposed a $t$-bar statistic based on the mean of the individual ADF statistics to investigate the panel data unit root assumption. The authors claimed that their $t$-bar statistic has a more precise size and higher power than the data panel unit root test of Levin and Lim (1993), taking into account residual heterogeneity and serial correlation between groups. For a sample of $\mathrm{n}$ observed groups over period $t$, the unit root regression of the conventional $\mathrm{ADF}$ test data panel is given by:

$$
\triangle Y_{i t}=\alpha_{i}+\beta_{i} Y_{i t-1}+\sum_{j=1}^{p_{i}} \gamma_{i j} \Delta Y_{i t-j}+\varepsilon_{i t} \forall i=1 \ldots n \text { and } \forall t=1, \ldots, T
$$

where $Y_{i t}$ is the study variable for country $i$ during the period $t ; \Delta$ denotes the first difference operator; $\alpha_{i}, \beta_{i}$, and $\gamma_{i j}$ are the coefficients to be estimated; and $\varepsilon_{i t}$ is the error term. Im et al. (1997) proposed to test the null assumption of data panel unit root as follows:

$$
\left\{\begin{array}{l}
H_{0}: \beta_{i}=0 \forall i \\
H_{1}: \beta_{i}<0 \forall i=1,2, \cdots, N_{1} \text { et } \forall i=N_{1}+1, N_{2}+2, \cdots, N
\end{array}\right.
$$

The equation for the alternative hypothesis allows the coefficient to differentiate between groups and is more general than the homogeneous alternative hypothesis, namely, $H_{1}: \beta_{i} \beta_{i}=$ $\beta<0 \forall i$.

Im et al. (1997) proposed a standardized $t$-bar statistic given by:

$$
\psi_{\bar{t}}=\frac{\sqrt{ } n\left\{\bar{t}_{n T}-(1 / n) \sum_{i=1}^{n} E\left[t_{i, T}\left(p_{i}, 0\right) \mid \beta_{i}=0\right]\right.}{\sqrt{1 / n} \sum_{i=1}^{n} \operatorname{Var}\left[t_{i, T}\left(p_{i}, 0\right) \mid \beta_{i}=0\right]}
$$

where $\left.\bar{t}_{n T}=\frac{1}{N} \sum_{i=1}^{n} E\left[t_{i, T}\left(p_{i,}\right) \beta_{i}\right)\right]$ and $t_{i, T}\left(p_{i}\right) \beta_{i}$ is the individual $t$ statistic to test the null assumption $\beta_{i}=0 \forall i$. Note that $E\left[t_{i, T}\left(p_{i}, 0\right) \mid \beta_{i}=0\right]$ and $\operatorname{Var}\left[t_{i, T}\left(p_{i}, 0\right) \mid \beta_{i}=0\right]$ are reported in Table (2) of Im et al. (1997) and vary when the ADF regression lag length varies. In practice, we use the same lag length in all the individual ADF regressions. Under the null assumption, the standardized statistic $\psi_{\bar{t}}$ is asymptotically standard distributed, $\psi_{\bar{t}} \sim N(0,1)$.

Im et al. (1997) used a Monte Carlo simulation and found that the finite samples for statistic $\psi_{\bar{t}}$ performed better than with the Levin and Lin (1993) test. If the variables are characterized by common trends, the individual ADF regression errors could be simultaneously correlated. The error term $\varepsilon_{i t}$ is supposed to be composed of two random components: 


$$
\varepsilon_{i t}=\theta_{t}+\vartheta_{i t}
$$

where $\theta_{t}$ is a common specific individual and stationary effect that takes into account one dependence degree between groups, and $\vartheta_{i t}$ represents an idiosyncratic (specific) random effect independently distributed between groups. According to Im et al. (1997), the simultaneous correlations of errors from individual ADF regressions can affect the critical values and power of data panel unit root tests.

\section{Madalla and wu test (1999)}

The Fisher test developed by Madalla and Wu (1999) highlights the $P$-values of $\rho_{i}$ from the $\mathrm{ADF}$ regression for each of the $\mathrm{ADF}$ regressions derived from the following Equation:

$$
\triangle Y_{i t}=\alpha_{i}+\beta_{i} Y_{i t-1}+\sum_{j=1}^{p_{i}} \gamma_{i j} \Delta Y_{i t-j}+\varepsilon_{i t} \forall i=1 \ldots n \forall t=1, \ldots, T .
$$

The Madalla and $\mathrm{Wu}$ (1999) test is not parametric and is based on Fisher (1932). Furthermore, this test is similar to the Im et al. (2003) test because it considers the different first-order autoregression correlations and has the same assumptions (null and alternative) in the estimation procedure. The Fisher test statistic $P(\lambda)$ is given as follows:

$$
P(\lambda)=-2 \sum_{i=1}^{n} \ln \left(\pi_{i}\right)
$$

where $\pi_{i}$ is the test statistic $P$-value for individual $i$. The Fisher test statistic $P(\lambda)$ follows a $\chi^{2}(2 n)$ statistic law. Maddala and $\mathrm{Wu}$ (1999) showed that the Fisher test has a more precise size and higher power compared with the test of Levin and Lim (1993). The advantage of the Fisher test is that it allows the use of different lags in the individual ADF regressions, although the Im et al. (2003) test requires the same individual regressions lag length.

According to Banergie (1999) and Maddala and Wu (1999), the Fisher test is highly useful in practice because it reduces the bias caused by the optimal lag selection procedure. Furthermore, three other statistics are used to test the null assumption that stipulates that each panel contains unit roots.

$$
Z=\frac{1}{\sqrt{N}} \sum_{i=1}^{N} \phi^{-1}\left(p_{i}\right) \rightarrow N(0,1)
$$

where $\phi^{-1}($.$) is the inverse of the standard normal function distribution.$ 


$$
L^{*}=\sqrt{\frac{3(5 N+4)}{\pi^{2} N(5 N+2)}} \sum_{i=1}^{N} \ln \left(\frac{p_{i}}{1-p_{i}}\right) \rightarrow t(5 n+4) .
$$

Under the null assumption, if $T \rightarrow \infty$, then by $N \rightarrow \infty$, the statistic $P$ tends toward infinity. Thus, Choi (2001a) proposed a modified $\chi^{2}$ and noted $P_{m}$, which converges to a standard normal distribution $(N(0,1))$.

$$
P_{m}=-\frac{1}{\sqrt{N}} \sum_{i=1}^{N}\left[\ln \left(p_{i}\right)+1\right] \rightarrow N(0,1)
$$

\section{Hadri (2000) LM test}

The Hadri (2000) LM test uses panel data to test the null hypothesis that the data are stationary versus the alternative that at least one panel contains a unit root. The test is designed for cases with large $T$ and moderate $N$. The motivation for the test is straight forward. Suppose we include a panel-specific time trend (using the trend option with xtunitroot hadri) and write our series, $y_{i t}$, as:

$$
y_{i t}=r_{i t}+\beta_{i} t+\varepsilon_{i t}
$$

where $r_{i t}$ is a random walk:

$$
r_{i t}=r_{i, t-1}+\mu_{i t}
$$

\section{B. Optimal lag selection}

In this work, we attempt to determine the optimal lag number of the model ARDL ( $\mathrm{p}, \mathrm{q}$, q, q). Subsequently, we attempt to interpret the results of the different estimators; namely, MG, PMG, and DFE. The optimal lags for the global sample of countries are reported in Tables 3 and 4, and the most common lags between countries are chosen. Specifically, we choose the most frequent number for all countries and for each variable used by referring to the AIC criterion. The ARDL $(1,2,0,0)$ is chosen for lower-middle-income countries. However, the $\operatorname{ARDL}(1,2,1,0)$ is chosen for upper-middle-income countries.

Tables 5 and 6 report the cointegration test results. We note that the different statistics are significant and greater than 1.96 in absolute value, indicating a cointegrating relationship. 
Table 3. Optimal lag selection (lower-middle-income countries)

\begin{tabular}{|c|c|c|c|c|}
\hline Variables & $G D P$ per capita & $\operatorname{Ln}(F D I)$ & $\ln T R$ & $O D A$ \\
\hline & \multicolumn{4}{|c|}{$\operatorname{ARDL}(\mathrm{p}, \mathrm{q}, \mathrm{q}, \mathrm{q})$} \\
\hline \multicolumn{5}{|l|}{ Countries } \\
\hline Bangladesh & 1 & 2 & 1 & 0 \\
\hline Bolivia & 1 & 2 & 0 & 0 \\
\hline Cameron & 1 & 1 & 0 & 0 \\
\hline Ivory Coast & 2 & 1 & 1 & 0 \\
\hline Egypt & 2 & 1 & 1 & 0 \\
\hline El Salvador & 1 & 2 & 0 & 1 \\
\hline Ghana & 1 & 1 & 0 & 1 \\
\hline Guatemala & 2 & 2 & 0 & 0 \\
\hline Honduras & 1 & 2 & 0 & 2 \\
\hline India & 1 & 2 & 1 & 0 \\
\hline Indonesia & 1 & 2 & 1 & 0 \\
\hline Kenya & 2 & 2 & 0 & 0 \\
\hline Morocco & 1 & 1 & 2 & 0 \\
\hline Nigeria & 2 & 2 & 0 & 1 \\
\hline Pakistan & 1 & 0 & 0 & 0 \\
\hline Philippines & 1 & 2 & 1 & 0 \\
\hline Sudan & 1 & 1 & 0 & 2 \\
\hline Tunisia & 1 & 2 & 0 & 0 \\
\hline
\end{tabular}

Table 4. Optimal lag selection (upper-middle-income countries)

\begin{tabular}{|c|c|c|c|c|}
\hline Variables & $P I B$ & $\operatorname{lnIDE}$ & $\ln T R$ & $A P D$ \\
\hline & \multicolumn{4}{|c|}{$\operatorname{ARDL}(p, q, q, q)$} \\
\hline \multicolumn{5}{|l|}{ Pays } \\
\hline Algeria & 1 & 2 & 0 & 2 \\
\hline Argentina & 1 & 0 & 0 & 2 \\
\hline Botswana & 1 & 2 & 1 & 0 \\
\hline Brazil & 2 & 2 & 1 & 2 \\
\hline China & 1 & 0 & 0 & 0 \\
\hline Colombia & 1 & 2 & 1 & 0 \\
\hline Costa Rica & 1 & 0 & 0 & 0 \\
\hline Malaysia & 1 & 2 & 1 & 0 \\
\hline Mexico & 2 & 2 & 1 & 0 \\
\hline Namibia & 1 & 1 & 1 & 0 \\
\hline Panama & 1 & 2 & 0 & 0 \\
\hline Peru & 1 & 2 & 0 & 0 \\
\hline Thailand & 2 & 1 & 1 & 0 \\
\hline Turkey & 2 & 2 & 1 & 0 \\
\hline Venezuela & 1 & 1 & 2 & 0 \\
\hline
\end{tabular}


Table 5. Cointegration test (lower-middle-income countries)

\begin{tabular}{ccc}
\hline Test stats & Panels & Group \\
\hline$v$ & 1.954 & \\
$r h o$ & -4.028 & -2.788 \\
$t$ & -8.692 & -9.687 \\
ADF & -6.81 & -7.04 \\
\hline
\end{tabular}

Table 6. Cointegration test (upper-middle-income countries)

\begin{tabular}{ccc}
\hline Test stats & Panels & Group \\
\hline$v$ & 1.114 & \\
$r h o$ & -4.851 & -4.395 \\
$t$ & -11.58 & -14.78 \\
ADF & -6.583 & -6.499 \\
\hline
\end{tabular}

All countries are ranked into two groups according to income level by refocusing to 2017 World Bank Classification. Tables 7 and 8 report the results of the short- and long-term effects of FDI, remittances, and ODA on economic growth using the following three estimators: $\mathrm{MG}$, PMG, and DFE.

Considering lower-middle-income countries, the results of the estimates confirm the existence of a long-term relationship because the adjustment coefficient (error correction parameter) is negative and statistically significant at the $1 \%$ level. The hypothesis of the homogeneity of the long-term coefficients can be verified using the Hausman test. We find that the PMG estimator is more consistent and efficient. Indeed, according to the Hausman test that allows choosing between MG and PMG on one hand and between PMG and DFE on the other hand, we note that this test is statically insignificant. Therefore, we focus on our interpretation of the PMG estimator that allows an analysis of the long-term effects.

The results show that the long-term impact of the overall sample, even if short-term FDI negatively affects economic growth, is insignificant in the long term. This result implies that a $1 \%$ increase in FDI leads to a $2.3785 \%$ decrease in economic growth, indicating that FDI inflows in developing countries are a disadvantage for economic growth. This result can be explained by the fact that FDI inflows can compel certain small firms to close because of competitive pressure or removal of planned investments. This result is consistent with several previous studies on the linkage between FDI and economic growth (Borenzstein et al. 1998, Mody and Mushid 2005, Wang (2010), and Morrissey and Udomkerdmongkol 2012).

In contrast, even if migrant remittances crowd out short-term economic growth, the long-term effect is not significant. These findings imply that remittances have no significant long-term effect on economic growth. In the short term, a $1 \%$ increase in remittances results in a $1.6741 \%$ decrease in economic growth, indicating that remittance inflows in developing countries are 
Table 7. MG, PMG, and DFE estimators: empirical results (lower-middle-income countries)

\begin{tabular}{|c|c|c|c|c|c|}
\hline & \multicolumn{5}{|c|}{ GDP per capita (dependent variable) } \\
\hline & MG & & PMG & & DFE \\
\hline \multicolumn{6}{|l|}{ Long-term coefficients } \\
\hline \multirow[t]{2}{*}{$\ln (F D I)$} & -0.0417 & & 0.0141 & & 0.0851 \\
\hline & $(0.9540)$ & & $(0.9320)$ & & $(0.6790)$ \\
\hline \multirow[t]{2}{*}{$\ln (T R)$} & 0.5424 & & 0.1496 & & $0.3180 * * *$ \\
\hline & $(0.2270)$ & & $(0.4127)$ & & $(0.0680)$ \\
\hline \multirow[t]{2}{*}{$O D A$} & 7.4358 & & 0.0017 & & -0.0106 \\
\hline & $(0.2670)$ & & $(0.8154)$ & & $(0.7410)$ \\
\hline Hausman test & & $\begin{array}{c}1.25 \\
(0.7404)\end{array}$ & & $\begin{array}{c}0.57 \\
(0.9041)\end{array}$ & \\
\hline ECM & $-0.8375^{*}$ & & $-0.8907^{*}$ & & $-0.8897 *$ \\
\hline Phi & $(0.0000)$ & & $(0.0000)$ & & $(0.0000)$ \\
\hline \multicolumn{6}{|l|}{ Short-term coefficients } \\
\hline \multirow[t]{2}{*}{$D \ln (F D I)$} & $-2.8971^{*}$ & & $-2.3785^{*}$ & & $-1.4197^{*}$ \\
\hline & $(0.0060)$ & & $(0.0041)$ & & $(0.0000)$ \\
\hline \multirow[t]{2}{*}{$\operatorname{Dln}(T R)$} & $-2.1892^{*}$ & & $-1.6741^{* *}$ & & $-1.3900 *$ \\
\hline & $(0.0040)$ & & $(0.0250)$ & & $(0.0000)$ \\
\hline \multirow[t]{2}{*}{$D(O D A)$} & -7.1798 & & -8.5894 & & -0.0452 \\
\hline & $(0.1970)$ & & $(0.1170)$ & & $(0.1340)$ \\
\hline \multirow[t]{2}{*}{ Constante } & 2.6892 & & $1.7444^{*}$ & & $1.8983 *$ \\
\hline & $(0.1410)$ & & $(0.0000)$ & & $(0.0000)$ \\
\hline
\end{tabular}

(Note) $*, * *$, and $* * *$ indicate significance at $1 \%, 5 \%$, and $10 \%$, respectively.

detrimental to economic growth. The insignificance of migrant remittances in long-term economic growth shows that remittances are often transferred through informal channels, such as friends and family members traveling abroad. In other words, remittances to developing countries occur through informal channels. This poses a major challenge for developing countries in developing their financial systems. Our results are consistent with those of Chami et al. (2010), Fenny et al. (2013), and Lim and Simmons (2015). However, transfers negatively affect short-term economic growth. This effect can be explained by the massive inflows of migrants' remittances that cause the real exchange rate to appreciate. This appreciation reduces the competitive strength of exports (Okodua and Olayiwola 2013). Moreover, these transfers trigger the consumption expenditures attributable to imports (Farzanegan and Hassan 2016).

In addition, results suggest that the effect of ODA is insignificant in both the long and short terms. This result is consistent with previous studies (Dhakal et al. 1996, Burnside and Dollar 2000, Adedokun 2017) that demonstrated that ODA is effective in well-governed countries. However, this result can be explained by the dependence of some developing countries 
Table 8. MG, PMG, and DFE estimators: Empirical results (upper-middle-income countries)

\begin{tabular}{|c|c|c|c|c|c|}
\hline \multicolumn{6}{|c|}{ GDP per capita (dependent variable) } \\
\hline & MG & & PMG & & DFE \\
\hline \multicolumn{6}{|c|}{ Long-term coefficients } \\
\hline \multirow[t]{2}{*}{$\ln (F D I)$} & -1.2855 & & -0.3152 & & -0.3571 \\
\hline & $(0.2500)$ & & $(0.3290)$ & & $(0.4230)$ \\
\hline \multirow[t]{2}{*}{$\ln (T R)$} & 0.9046 & & 0.2245 & & 0.2158 \\
\hline & $(0.2790)$ & & $(0.4120)$ & & $(0.4590)$ \\
\hline \multirow[t]{2}{*}{$O D A$} & 20.4007 & & $-0.654 * * *$ & & $-1.0449 * *$ \\
\hline & $(0.2610)$ & & $(0.0600)$ & & $(0.0200)$ \\
\hline Hausman test & & $\begin{array}{c}1.32 \\
(0.7255)\end{array}$ & & $\begin{array}{c}0.2300 \\
(0.9719)\end{array}$ & \\
\hline ECM & $-0.9053^{*}$ & & $-0.8090 *$ & & $-0.8337^{*}$ \\
\hline Phi & $(0.0000)$ & & $(0.0000)$ & & $(0.0000)$ \\
\hline \multicolumn{6}{|c|}{ Short-term coefficients } \\
\hline \multirow[t]{2}{*}{$D \ln (F D I)$} & $-3.9053 * * *$ & & $-2.733 * * *$ & & $-3.8219 *$ \\
\hline & $(0.0880)$ & & $(0.0540)$ & & $(0.0000)$ \\
\hline \multirow[t]{2}{*}{$\operatorname{Dln}(T R)$} & $-2.3146^{*}$ & & $-2.1132 *$ & & $-1.7175^{*}$ \\
\hline & $(0.0000)$ & & $(0.0010)$ & & $(0.0000)$ \\
\hline \multirow[t]{2}{*}{$D(O D A)$} & -20.0204 & & $-23.88 * * *$ & & $0.6913 * * *$ \\
\hline & $(0.1630)$ & & $(0.0910)$ & & $(0.0860)$ \\
\hline \multirow[t]{2}{*}{ Constante } & $5.5748 * * *$ & & $3.2183^{*}$ & & $3.9302 *$ \\
\hline & $(0.0920)$ & & $(0.0000)$ & & $(0.0010)$ \\
\hline
\end{tabular}

(Note) $*, * *$, and $* * *$ indicate significance at $1 \%, 5 \%$, and $10 \%$, respectively.

on aid. As a result of receiving significant assistance, developing countries-especially the poorest and those with low incomes-have become highly dependent. Economic growth in developing countries has weakened despite massive flows of ODA. Therefore, official ODA pushes developing countries to be linked to the famous "debt trap" (Mallik 2008).

Concerning upper-middle-income countries, results indicate that the effect of FDI on economic growth is significant in the long term and not significant in the short term. However, migrant remittances negatively affect economic growth in the short run, and the impact is statistically significant. In the long term, this effect is positive and not significant. This result is confirmed by the work developed by Chami et al. (2010), who noted that the impact of remittances on economic growth is insignificant in the long term because remittances are often transferred through informal channels, such as friends and family members traveling abroad, or informal money-transfer networks such as the "hawala" system.

Finally, ODA has a negative and significant long-term effect on economic growth. Sothan (2018) investigated the effect of foreign aid on economic growth in Cambodia over the period 1980 2014 using the ARDL. He found that foreign aid has a negative and significant effect 
on long-term economic growth.

\section{Conclusion and Policy Implications}

This article mainly examines the interaction among economic growth and the three financial flows of FDI, ODA, and personal remittances. We apply the panel ARDL model to analyze the short- and long-term effects of each financial flow on economic growth. Moreover, we consider a panel of 33 developing countries divided into two group such as: the lower-middle-income countries and the upper-middle-income countries. for the period 1990 2017. The results confirm the existence of a long-term relationship because the adjustment coefficient (error correction parameter) is negative and statistically significant. We find that the PMG estimator is more consistent and efficient. In the short run, the effect of foreign direct investment on economic growth is negative and statistically significant. However, it is not significant in the long run. On the other hand, the effect of remittances on economic growth is negative and significant in the short run. However, it is not significant in the long run. Finally, the results suggest that the effect of ODA on economic growth is insignificant in both the short and long terms.

The main policy implications arising from our study can be presented as follows:

Regarding FDI, developing countries should improve their business environment and establish a facilitating framework for both domestic and foreign investors. Several countries have already taken such measures, but much remains to be achieved in this direction.

Providing reliable information to migrants about transfer services and their costs is necessary. Developing countries should direct informal transfers to formal transfers to increase the tax base and allow greater divestment in government's hands, such as developing official money-transfer agencies in all regions, including rural areas, and reducing taxes on foreign currency deposits.

The aid received by developing countries is marred by the issue of corruption. Therefore, developing countries need to improve their governance to better manage the aid received and, thus, increase the economic benefit of such aid.

\section{References}

Adedokun A. J. (2017). "Foreign aid, governance and economic growth in sub-saharan Africa: Does one cap fit all?", African Development Review, 29, no. 2, 184-196.

Almfraji, M. A., Almsafir, M. K., and Yao, L. (2014). "Economic growth and foreign direct investment inflows: the case of Qatar." Procedia-Social and Behavioral Sciences, 109, 1040-1045.

Asteriou, D., and Monastiriotis, V. (2004). "What do unions do at the large scale? Macro-economic 
evidence from a panel of OECD countries." Journal of Applied Economics, 7, no. 1, 27-46.

Banerjee A. (1999). "Panel data unit roots and cointégration: an over view", Oxford Bulletin of Economics and Statistics 61, 607-629.

Bhavan T., Xu C., and Zhong C. (2011). "The relationship between foreign aid and FDI in South Asian economies." International Journal of Economics and Finance 3, no. 2, May 2011.

Blackburne E. F., and M. W. Frank (2007). "Estimation of nonstationary heterogeneous panels." Stata Journal, 7, 197-208.

Borensztein E., Gregorio J., and Lee J. (1998). "How does foreign direct investment affect economic growth", Journal of International Economics, 45, no. 1, 115-135.

Burnside C., and Dollar D. (2000). "Aid, policies, and growth." American Economic Review, 90, 4, 847-868.

Caves Richard. (1996). Multinational enterprises and economic analysis, the 2nd edition, Cambridge, MA: Cambridge University Press.

Chami M R., Barajas M A., Garg A., and Fullenkamp C. (2010). "The global financial crisis and workers' remittances to Africa: What's the damage?" 10-24, International Monetary Fund.

Choi I. (2001a). "Unit root tests for panel data." Journal of International Money and Finance, 20, 249ñ272.

Coon M., and Neumann R. (2015). "Follow the money: Remittance responses to FDI inflows", MPRA Paper, 62220.

Dhakal D., Upadhyaya K., and Upadhyaya M.. (1996). "Foreign aid, economic growth and causality", Rivista Internazionale di Scienze Economiche e Commerciali, 43, 597-606.

Driffield, N., and Jones, C. (2013). "Impact of FDI, ODA and migrant remittances on economic growth in developing countries: A systems approach.” The European Journal of Development Research, 25, no. 2, 173-196.

Farzanegan M R., and Hassan S M. (2016). "How does the flow of remittances affect the trade balance of the Middle Eastern and North Africa?", Macie Paper series, Nr. 2016/13, Marburg Centre of Instituational Economics, Marburg, Germany.

Fenny S., Iamsiraroj S., and Mc Gillivray M. (2013). "Remittances and economic growth: Larger impacts in Smaller Countries." Journal of Development Studies, 50, 8, 1055-1066.

Haddad M., and Harrison. (1993). "Are there positive spillovers from direct foreign investment? Evidence from panel data for Morocco", Journal of Development Economics, 42, no. 1, 51-74.

Hadri K. (2000). "Testing for stationarity in heterogeneous panel data", Econometrics Journal, 3, 148-161. Helpman E. (1984). "A simple theory of international trade with multinational corporations." Journal of Political Economy 92:451ó71.

Im K. S., Pesaran M. H, and Shin Y. (1997). "Testing for unit roots in heterogeneous panels", Working paper, Department of Applied Economics, University of Cambridge.

Javaid W. (2017). "Impact of remittances on consumption and investment: Case study of Tehsil Sargodha, Punjab, Pakistan." Journal of Finance and Economics, vol. 5, no. 4, 156- 163.

Karakaplan U, B., and Neyapti, S Sayek (2005). "Aid and foreign direct investment: International evidence", Discussion Paper, Turkish Economic Association, No. 2005/12.

Kodama M. (2012). “Aid unpredictability and economic growth.” World Development 40, no. 2, 266- 272. Lahiri S., and Raimondos-Moller P. (2000). "Lobbying by ethnic groups and aid allocation." The Economic 
Journal, 110, C62-C79.

Lensink R., and O. Morrissey (2000). "Aid instability as a measure of uncertainty and the positive impact of aid on growth." Journal of Development Studies, 36, no. 3, 31-49.

Levin A., and Lin C.F (1993). "Unit root test in panel data: new results", Discussion paper 93-56, Department of Economics, University of California at San Diego.

Lim S., and Simmons W. O. (2015). "Do remittances promote economic growth in the Caribbean community and common market?" Journal of Economics and Business, 77, 42-59.

Maddala G.S., and Wu S. (1999). "A comparative study of unit root tests with panel data and a new simple test", Oxford Bulletin of Economics and Statistics 61, 631-652.

Mallik G. (2008). "Foreign aid and economic growth: A cointegration analysis of the six poorest African Countries", Economic Analysis and Policy, 38, 251-260.

Minasyan A., and P. Nunnenkamp (2016). "Remittances and the effectiveness of foreign aid." Review of Development Economics, 20, no. 3, 681-701.

Minoiu C., and Reddy S. (2008). "Development aid and economic growth: A positive long term relation", Unpublished manuscript. Available on: http://papers.ssrn.com/sol3/papers.cfm?abstract_id=903865.

Mody A., and Murshid A. (2005). "Growing up with capital flows", Journal of International Economics, 65, no. 1, 249-266.

Morrissey O., and Udomkerdmongkol M. (2012). "Governance, private investment and foreign direct investment in developing countries", World Development, 40, no. 3, 437-445.

Nwaogu, U. G., and Ryan, M. J. (2015). "FDI, foreign aid, remittance and economic growth in developing countries." Review of Development Economics, 19, no. 1, 100-115.

Okodua H., and Olayiwola W. (2013). "Migrant workers' remittances and external trade balance in Sub-Sahara African Countries", International Journal of Economics and Finance, 5, no. 3, 134-142.

Olubiyi E. A. (2014). "Trade, remittances and economic growth in Nigeria: Any causal relationship?." African Development Review, 26, no. 2, 274-285.

Ouattara B. (2006). "Foreign aid and government fiscal behavior in developing countries: Panel data evidence", Economic Modeling, 23, 506-514.

Pesaran H., and Smith R. (1995). "Estimating long-term relationships from dynamic heterogeneous panels", Journal of Econometrics, 68, 79-113.

Pesaran M H., and Shin Y. (1996). "Cointegration and speed of convergence to equilibrium", Journal of Econometrics, 71, 117-143.

Pesaran M H., Shin Y., and Smith R P (1999). "Pooled mean group estimation of dynamic heterogeneous panels", Journal of the American Statistical Association, 94, no. 446, 621-634.

Selaya P., and Sunesen E.R. (2008). Does foreign aid increase foreign direct investment? Discussion Paper, University of Copenhagen, ISSN: 1601-2461. [Online] Available: http://ideas.repec.org/p/kud/k uiedp/0804.html.

Sothan, S. (2018). "Foreign aid and economic growth: evidence from Cambodia." The Journal of International Trade \& Economic Development, 27, no. 2, 168-183.

Wang Miao (2010). "Foreign direct investment and domestic investment in the host Country: Evidence from panel study", Applied Economics, 42, 3771-3721. 